\title{
Meta-Model of EPortfolio Usage in Different Environments
}

\author{
http://dx.doi.org/ijet.v6i3.1594 \\ I. Balaban ${ }^{1}$, B. Divjak ${ }^{1}$ and E. $\mathrm{Mu}^{2}$ \\ ${ }^{1}$ University of Zagreb, Faculty of Organization and Informatics, Varazdin, Croatia \\ ${ }^{2}$ Carlow University, Pittsburgh, USA
}

\begin{abstract}
EPortfolio offers a new philosophy of teaching and learning, giving the learner an opportunity to express oneself, to show one's past work and experience to all the interested parties ranging from teachers to potential employers. However, an integral model for ePortfolio implementation in academic institutions that would take into account three different levels of stakeholders: 1. Individual (student and teacher); 2. Institution; and 3. Employer, currently does not exist. In this paper the role of ePortfolio in academic environment as well as the context in which ePortfolio operates is analyzed in detail. As a result of the comprehensive analysis that takes into account individual, academic institution and employer, a meta-model of ePortfolio usage in Lifelong Learning is proposed.
\end{abstract}

Index Terms - Portfolios, Metamodeling, Learning systems

\section{INTRODUCTION}

When educational institutions embraced e-learning for the first time, they realized they needed to adjust their business (i.e. teaching and learning) processes to fully utilize the new concept. Eportfolio is defined as $\boldsymbol{a}$ personal digital record that supports Lifelong Learning and contains evidence about one's accomplishments in the form of artefacts which can be provided to whomever the owner has chosen to grant permission. As an extension of e-learning, it aims to remove obstacles between the learner's 'inner world' and the 'outside world'. A learner's 'inner world' includes a Learning Management System (LMS), which used to be considered an environment closed to an audience and was limited to the learner and the learning organization. The 'outside world' includes procedures, events, systems, people and other entities that do not have permission to view an individual's personal or private learning data from their 'inner world'. EPortfolio, on the contrary, offers a new approach, a new philosophy of teaching and learning, giving the learner an opportunity to express oneself, to show one's past work and experience to all the interested parties ranging from teachers to potential employers (see [1], [6], [7], [23] and [35]). As far as an academic organization is concerned, this calls for new adjustments in both the system and the process because ePortfolio is not merely a technology. It is a whole new set of educational rules and approaches that should be incorporated into academic organizations curricula (see
[15], [33], [39] and [41]). By eliminating a strict division between the learner's 'inner world' and the 'outside world', both 'worlds' have gained something valuable. Moreover, a new entity has appeared in the process of Lifelong Learning, i.e. the employer. With ePortfolio, the learner has the ability to show their work to the educator as well as to the potential employer. According to [14], the benefits of ePortfolios in education are numerous, serving a number of purposes and stakeholders, including: helping the student to develop organizational skills; recognize skills, abilities, and shortcomings; assess their progress; demonstrate how skills are developed over time; make career decisions; and promote themselves professionally. As a result, ePortfolio implementation in an academic institution is by no means simple because it involves several entities ([23], [25]). Consequently, an extended study is required to enable all the parties involved, i.e. the learner, educator, organization and potential employer, to benefit most from its implementation (for examples, see [23]).

An integral model for ePortfolio implementation in academic institutions that would take into account three different levels of stakeholders: 1. Individual (student and teacher); 2. Institution; and 3. Employer, has not been developed. A lot of research on ePortfolio (see [8], [18], [31], [37], [39] and [40]) mainly focuses on the process of its development within an institution, defining ePortfolio requirements and case studies of institutions that have implemented ePortfolio on the course level.\# Moreover, the promising strands of ePortfolio research include identifying the impact ePortfolio has on job quality [40], taking into account all the possible future users, potential benefits and its universality [28].

In this paper the role of ePortfolio in academic environment as well as the context in which ePortfolio operates is analyzed in detail. Such analysis is vital for understanding the purpose of ePortfolio since its implementation and usage starts in academic environment and follows the Lifelong Learning paradigm toward employability and personal growth and development. As a result of the comprehensive analysis that takes into account individual, academic institution and employer, a meta-model of ePortfolio is proposed.

\section{UNDERSTANDING THE ROLE OF PORTFOLIO IN ACADEMIC ENVIRONMENT}

When implementing and using ePortfolio, three major management levels in organization are to be taken into consideration (see Table 1). This is consistent with traditional organization management as well as with 
levels of IS support (for example see [29]). The implementation process should be introduced at all the three levels to ensure that this phenomenon is fully embraced by an academic institution. Of course, step-bystep implementation is also possible and may be the one most often used, especially with pilot projects. The three levels identified are common in every business environment. They correspond to (1) strategic level; (2) tactical level; and (3) operating level in organization management.

The strategic level of implementation can be identified by the institution's Mission, Vision and Strategy. Starting from the top of the academic organization's structure and having in mind its mission, vision and strategy, it is considered that ePortfolios should be integrated into the curriculum because they are shifting the control towards the learner enabling studentcenteredness and adoption of new learning models. In that way they are inevitably affecting curriculum design and development. EPortfolio will become a societal need in near future, and if they are not implemented into the curriculum "they may never fulfill their potential and become a tool that alters learning pedagogy" [41]. EPortfolio requires changes in the curriculum that was based on traditional pedagogic methods. A learner will have the opportunity to show their accomplishments to the society, to learn from the populace and to share resources with the global community.

A few other examples of embedding ePortfolio into the curriculum can be found in [15], [33] and [39]. The University of Strathclyde in Glasgow, Scotland and Alverno College in Milwaukee embraced the idea of embedding personal development planning into the curriculum. As a result, the institutions' strategies as well as teaching and learning processes were changed accordingly, thus enabling personal development planning supported by ePortfolio to be implemented.

Teaching and learning correspond to the tactical level. Both teaching and learning processes should be carefully designed bearing in mind the new pedagogical approach, ICT development and students' capabilities. It has been proven in several occasions that ePortfolio improves student learning. The case of ePortfolio implementation at Alverno College Faculty [33] is just one of the examples where ePortfolio served as a pedagogical tool and helped students to connect learning across courses, assisting the faculty to extend the learning terrain of their majors. It helped them to discover their learning patterns. Other authors [39] stress the proper use of ePortfolio in the assessment of knowledge as a key to successful ePortfolio implementation. The authors extensively describe issues related to the assessment process such as improving assessment reliability and authenticity, advantages of self and peer assessments, etc. Some of those issues need to be solved at the lower level within the ePortfolio system and need to be considered when choosing the ePortfolio system.

Infrastructure (both hardware and software) and user acceptance are the essential components at the operating level. Each of the two higher levels ultimately depends on this basic level of implementation. In order for all ePortfolio functionalities and benefits to find their application in an academic institution, two basic assumptions are: (a) to find the most appropriate ePortfolio system; and (b) to prepare (i.e. train) all the potential users to embrace the system. Research shows that students are by far the most satisfied users of the system with some exceptions (for examples, see [13], [26], [33] and [39]). Most of the previously mentioned research indicates that all faculty members including the management, teachers, students and IT administration staff were involved in the process of choosing and implementing the ePortfolio system. In case of the two courses at Montclair State University in New Jersey and East Stroudsburg University in Pennsylvania [17], ePortfolio implementation was performed step-by-step, from introducing the process, following the pre-designed templates for structure, to introducing the artefacts, tutorials and reflection. Choosing the adequate software that would support desired functionalities and requirements presented a challenge.

TABLE I.

OVERVIEW OF DIFFERENT MANAGEMENT LEVELS

\begin{tabular}{|c|c|c|c|}
\hline Level & Strategic & Tactical & Operating \\
\hline Description & $\begin{array}{l}\text { Identified by institution's } \\
\text { Mission, Vision and Strategy. }\end{array}$ & $\begin{array}{l}\text { Characterized by teaching and } \\
\text { learning processes. }\end{array}$ & $\begin{array}{l}\text { Includes infrastructure components and user } \\
\text { acceptance (the use of ePortfolio and user } \\
\text { satisfaction). }\end{array}$ \\
\hline $\begin{array}{l}\text { Basic } \\
\text { characteristics }\end{array}$ & $\begin{array}{l}\text { - EPortfolio integrated into } \\
\text { curriculum } \\
\text { - Assist in organization's } \\
\text { development } \\
\text { - Used for revision of study } \\
\text { programmes } \\
\text { - Align ePortfolio with } \\
\text { employability frameworks }\end{array}$ & $\begin{array}{l}\text { - Improves student learning (by } \\
\text { enabling reflections) } \\
\text { - Assist faculty to extend learning } \\
\text { terrain } \\
\text { - Assessment tool } \\
\text { - Improves self-presentation }\end{array}$ & $\begin{array}{l}\text { - All faculty staff should be involved in } \\
\text { choosing and implementing ePortfolio } \\
\text { - Implementation should be a step-by-step } \\
\text { process } \\
\text { - Education on use of ePortfolio (workshops, } \\
\text { helpdesk etc.) }\end{array}$ \\
\hline $\begin{array}{l}\text { Implementation } \\
\text { examples }\end{array}$ & $\begin{array}{l}\text { - Alverno College Faculty [33] } \\
\text { - Queensland University of } \\
\text { Technology (QUT) [15] } \\
\text { - University of Strathclyde [39] }\end{array}$ & $\begin{array}{l}\text { - Alverno College Faculty [33] } \\
\text { - Montclair State University [17] } \\
\text { - East Stroudsburg University [17] } \\
\text { - University of Strathclyde [39] }\end{array}$ & $\begin{array}{l}\text { - University of Dundee [13] } \\
\text { - Montclair State University [17] } \\
\text { - East Stroudsburg University [17] } \\
\text { - Virginia Tech's Department of } \\
\text { Communication [26] } \\
\text { - Queensland University of Technology [15] }\end{array}$ \\
\hline
\end{tabular}


Taking into consideration the experiences with ePortfolio implementation described in this section, we can conclude that the needs of learners in higher education are rapidly changing so it is very important to identify the existing requirements and anticipate some of those likely to emerge in near future. An appropriate mechanism can be embedded in all the three levels of organization's management to ensure that ePortfolio is well-accepted and judiciously used.

\section{THE CONTEXT IN WHICH EPORTFOLIO OPERATES}

In order to adequately comprehend ePortfolio functionalities it is necessary to understand the organizational environment in which ePortfolio operates, i.e. the User-Centered Lifelong Learning environment (UCLLL) with all its characteristics and subspaces (such as PLE).

\section{Lifelong Learning}

Lifelong Learning (LLL) represents a user-centered learning environment used throughout one's entire life encompassing all three learning forms: formal, nonformal and informal learning. The European Qualifications Framework (EQF) ${ }^{1}$, a common European reference framework that enables European countries to interlink their qualifications systems, distinguishes three forms of learning. According to [38] these forms can be defined as follows:

- Formal learning goes from preschool to graduate studies. It is highly institutionalized, hierarchical, includes a period called 'basic education', which is compulsory and implements a prescribed curriculum. Each level prepares learners for the next one, and to enter into a certain level it is prerequisite to satisfactorily complete the previous level. At the end of each level and grade, graduates are granted a diploma or a certificate.

- Non-formal learning refers to all organized educational programs that take place outside the formal schooling system, and are usually short term or voluntary. These programs usually do not require prerequisites in terms of previous schooling. Teachers and curriculum exist, but with much more flexibility than in formal education. An example of non-formal learning is driving lessons.

- Informal learning takes place outside the curricula provided by formal and non-formal educational institutions and programs. In the process of informal learning there are no educational institutions, instructions or prescribed curricula.

Most formal learning ends at some point of human life, usually after formal schooling. Unlike formal learning, informal learning starts almost from the birth, occurring in parallel with formal learning and lasts throughout one's entire life. Regardless of its type, we can say that 'modern' learning continues throughout the entire lifespan of an individual and combines all the aforementioned learning forms. Such a new way of

\footnotetext{
${ }^{1}$ EQF issued the Recommendations of the European Parliament and of the Council on establishment of the European Qualifications Framework for LifeLong Learning. The recommendations should contribute to modernising education and building bridges between formal, nonformal and informal learning..
}

understanding learning is referred to as Lifelong Learning (LLL). Therefore ePortfolios, except for providing an inventory of acquired knowledge and skills, should "have a richer purpose: to facilitate lifelong learning" [25]. Lifelong learners should actively use PLEs and PDPs and should be reflective learners. If we consider ePortfolio functionalities, it is therefore obvious that it could appropriately support LLL.

In other example [24] it is suggested that lifelong learners know what they know, what they have to learn, and what they can do for an employer. According to the same author, there is increasing evidence that LLL does not start after schooling ends. EPortfolio provides an environment for an individual to store and manage their artefacts throughout one's entire life. By facilitating reflections and feedbacks, ePortfolio supports both individual and collaborative learning that makes for a very important component in LLL. In other words, by supporting the processes in LLL, ePortfolio exceeds the boundaries of formal education and takes place throughout one's life.

PDP and PLE both represent 'virtual processes and environments' within LLL and occur in formal, nonformal and informal learning.

\section{Personal Development Plan}

One of the features that ePortfolio shares with elearning is that it enables individuals to set their learning goals or develop action plans for the future. By setting one's own learning goals, an individual can track their progress toward the achievement of each goal. In such a way, ePortfolio helps an individual to plan and track their personal development. In the United Kingdom, a PDP encompasses a number of activities such as [22]:

- Compiling a list of experiences or past activities, including employment;

- Reviewing past written goals and action plans against more recent past experience;

- Listing achievements/qualifications (with documentation if available);

- Relating experiences to skills (or vice versa);

- Reviewing personal interests;

- Setting goals for skills development;

- Setting goals related to subject development;

- Originating action plan for the achievement of academic goals;

- Revising CV/personal statement/other compilation;

- Revising action plan for personal goals in the context of feedback/discussion, etc.

Identifying the key components of a PDP is essential for creating Web-based IT systems that would support all the needed activities. In brief, a PDP can be described as a process of supporting an individual's theory of oneself as a learner. According to [22] "this happens as part of a reflective cycle which we characterize as having seven steps: noticing, documenting, recollecting, theorizing, goal setting, action planning, and acting". All these steps can be seen through the activities mentioned above. Today's ePortfolio systems can support most of these activities. 


\section{Personal Learning Environment}

Learning management systems have enabled the creation of the so-called Virtual Learning Environment (VLE) in which a learner can enroll. In a VLE, all the tools and materials needed in a course can be found in one place. Since the learner is virtually present in a virtual class, the environment created in such a way was named a VLE. Such an environment represented an organization-centered environment in which an individual was enrolled. By introducing ePortfolio, the centre was shifted from the organization and from VLEs towards another concept in which an individual plays the central role by using information from different sources. As a result, a new environment was created around the individual, called a Personal Learning Environment (PLE). That environment enables the learner to learn in different contexts thus combining formal and informal learning. According to [2], "the idea of a Personal Learning Environment recognizes that learning is ongoing and seeks to provide tools to support that learning". Consequently, PLE is actually a set of tools that an individual uses in their everyday life for learning. It can vary from a word processor, instant messaging tools, e-mail, LMS, to a wide range of Web 2.0 tools.

A number of different forms of learning, new approaches to assessment and fast-changing technologies exist nowadays. The purpose of contemporary and emerging technologies should be their adaptability to end-user needs (especially their learning styles) and simplicity or ease of use. It is not the user who should adapt to technology, but vice versa.

It can be clearly seen that in a PLE individuals can choose which tools they will use. Since an individual is the one who will 'fetch' all the necessary information from many different systems, ePortfolio should be the central system in a PLE to enable the individual to store, maintain and present the information obtained from various sources.

\section{META-MODEL OF EPORTFOLIO USAGE IN DIFFERENT ENVIRONMENTS}

Taking into consideration the role of ePortfolio in academic institution, the context in which it operates, its mission, vision and purpose, a new definition of ePortfolio is proposed. EPortfolio can thus be defined as a subsystem of a user-centered Lifelong Learning organization, whose task is to link processes on the operational, management and decision-making level and the goal of which is to improve personal competencies, support learning management and increase decision-making reliability regarding personal growth and development.

Having all that in mind and adding the extensive ePortfolio literature overview ([1], [6], [7], [8], [9], [10], $[11],[12],[13],[15],[16],[17],[19],[20],[25],[26]$, [27], [28], [30], [32], [35], [36], [37], [39], [40], [41] and [42]) as well as the author's own experience with
ePortfolio implementation and usage[5], a meta-model shown in Fig. 1 was developed to represent a possible usage of ePortfolio as a central system in Lifelong Learning. In the following sections it will be shown that the success of ePortfolio greatly depends on how well it supports all the possible processes in LLL. Five basic scenarios can be identified regarding ePortfolio usage in LLL that will be briefly described in the following part of this section.

\section{Scenario I: ePortfolio usage within an educational institution}

Three entities are present in this case: Student, Educator and Educational Institution. Since the primary function of ePortfolio is to support the learning process it is obvious that formal education is the point of departure. In this case Student collects, organizes and presents their data through ePortfolio. Educator can use the ePortfolio system in two ways: 1. To present their data and to contribute to the Institution's ePortfolio; and 2. To communicate with Students and support their learning process. Concerning its internal structure, every ePortfolio consists of two main parts: 1. Private: set of data in ePortfolio available only to the owner; and 2. Public: set of data grouped and published as an ePortfolio view to the wider audience.

Most ePortfolio views developed in the context of formal education are intended for assessment. The process will be simplified and described as follows:

1. Student creates a view that holds artefacts to be graded by Educator. Although in formal education it is common for Institution to host the ePortfolio system, in this case it is not relevant. An artefact can be sent for grading through the Institution's services, or it can be uploaded on the Institution's LMS.

2. Educator receives/downloads a Student's artefact, grades it and makes some comments and recommendations for improvement if needed.

3. The graded artefact is uploaded to LMS or some other service. During that procedure the artefact with its metadata (grade, comments, date, author, etc.) is certified by Institution to preserve its integrity and validity.

4. Student downloads/receives the certified artefact and stores it in ePortfolio for later usage.

5. By repeating steps 1 to 4, Student enriches their own ePortfolio with certified artefacts that will be used in the second step, i.e. the job application or job retention process.

Modern schooling offers students an opportunity to be mobile during the study period and spend it on different institutions (universities). EPortfolio can assist in this process and enable a quicker, easier and more transparent process of switching between institutions or study programmes in a way that competences and prior learning are documented and proven in an easy and transparent manner. 
EDUCATIONAL ORGANIZATION EMPLOYMENT ORGANIZATION

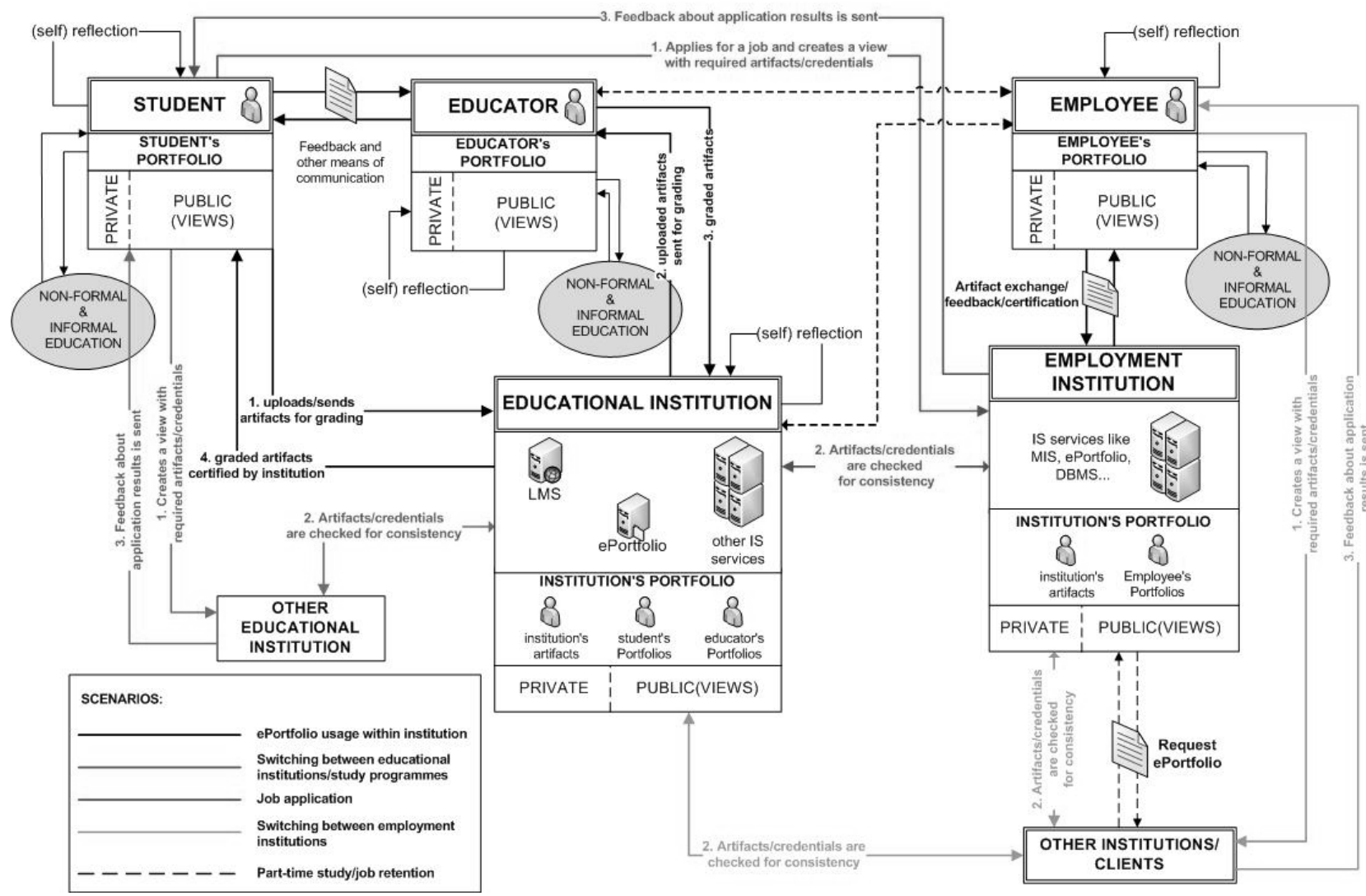

Figure 1. The ePortfolio meta-model

\section{Scenario II: Switching between educational} institutions/study programmes

Three entities included in the previous scenario remain present in this one as well, with the possible addition of another entity, i.e. another educational institution, which can basically be perceived as an Educational Institution entity.

1. Student creates a view and includes artefacts needed to apply for a study programme, change Educational Institution or simply spend one semester or year in a mobility scheme (for example, Erasmus). The view is published and a potential institution has access to it.

2. During education artefacts are certified by Educational Institution. This enables the Institution to check the consistency and validity of artefacts in a Student's ePortfolio.

3. Based on the results of audit from step 2 and the quality of the given credentials/artefacts, feedback is sent back to Student.

4. If Student returns to their home institution after a certain study period spent in mobility at a host institution, the home institution can find proofs of Student's achievements in ePortfolio.

After the student completes the formal education process it is time to apply for a job.

\section{Scenario III: Job application}

In this scenario, the student evolves into an employee. Different types of entities appear in this case: Student, Educational Institution and Employment Institution.

1. Student creates a view and includes artefacts needed for a job application. The view is published and a potential employer has access to it.

2. During education artefacts are certified by Educational Institution. This enables the potential employer to check the consistency and validity of artefacts in a Student's ePortfolio as well as to assess their quality and appropriateness.

3. Based on the results of audit from step 2 and the quality of the given credentials/artefacts, feedback is sent back to Student.

The artefact verification/certification process presents a very serious issue today and should therefore be addressed properly. To support this claim, a recent research should be mentioned which showed that in 91 ePortfolio systems not a single artefact could be verified for its consistency or validity [3]. Attempts have been made in order to address the artefact certification problem and a lightweight protocol as a possible solution was suggested [4].

On a different note, it has to be mentioned that the meta-model in this section shows general processes in a real (business) system that ePortfolio should support. It represents a basic view or a starting point in approaching 
ePortfolio as a concept. For every scenario described in the meta-model, more detailed decomposition can be made along with the corresponding model. In addition, the success of the ePortfolio system will be seen as a percentage in which ePortfolio can support all the required processes in a real system.

\section{Scenario IV: Switching between employment institutions}

This scenario is very similar to Case II scenario. Moreover, Case V scenario can be comprehended as Case II applied in an employment organization. Three main entities can be identified: Employee, Employer and Educational Institution. In addition, another employer to which an employee wants to apply for a job can also be identified, although technically this is still an instance of an entity named Employer.

1. Employee creates a view and includes artefacts needed to apply for a study programme or to change the institution. The view is published and a potential institution has access to it.

2. During education artefacts are certified by Educational Institution. This enables the Institution to check the consistency and validity of artefacts in an Employee's ePortfolio.

3. Based on the results of audit from step 2 and the quality of the given credentials/artefacts, feedback is sent back to Employee.

\section{Scenario V: Part-time study/job retention}

This is a combination of several scenarios presented so far. An individual is an employee but at the same time wants to continue their education. In most cases it is related to non-formal education, although in some countries it is organized as a part-time study in which an individual enrolls a university or a polytechnic. This scenario enables an individual to study and work at the same time using on-line or blended education. As in Case I, all the achievements in the form of artefacts can be signed and verified by the educational institution. Moreover, an individual can interact directly with the educator if needed. The results of an individual's working experience and education are stored in ePortfolio.

\section{Scenarios in LLL continuum}

In addition to scenarios, it is important to mention processes which occur in the life of every individual often considered as 'the background processes' that refer to non-formal and informal learning. Those are presented as ovals and also result in artefacts stored in ePortfolio. It is important to notice that the scenario sequence follows the LLL concept shown in Fig. 2. In Scenarios I and II the student acquires knowledge mainly during formal education. In addition to knowledge, they learn how to think and reflect. After formal schooling the student becomes an employee, as described in Scenarios III and IV. To stay competitive, they must enrich their knowledge throughout life. Therefore Scenario V shows the employee who acquires new knowledge through different education mechanisms and uses an ePortfolio to document their knowledge and accomplishments, show their competencies, and manage their own personal growth and development.

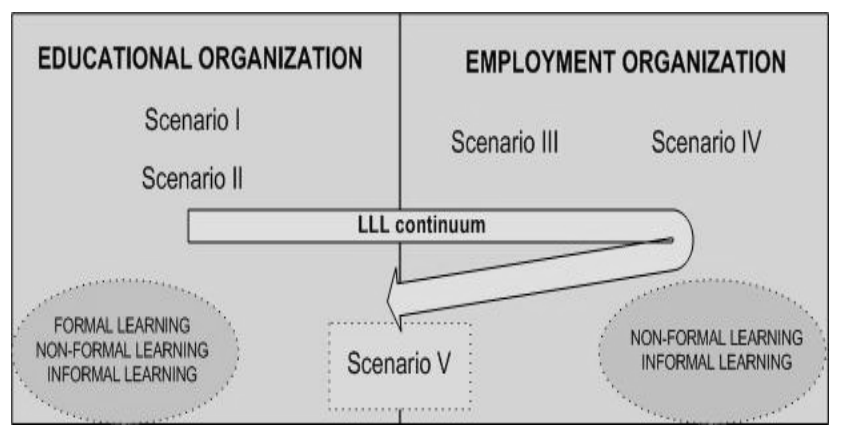

Figure 2. LLL continuum

\section{CONCLUSION}

The ePortfolio meta-model was developed as a result of the extensive ePortfolio literature overview and personal experience in ePortfolio usage and implementation. The aim of the meta-model is to help to comprehend the ePortfolio as a concept, including its mission and purpose. Moreover, that comprehensive fivescenario model is intended to depict a possible usage of ePortfolio as a central system in Lifelong Learning. In addition, the five scenarios show how ePortfolio should work or how it should provide support for an employment organization also. It can be valuable to individuals, educational institutions as well as employment organizations in explaining the information flow, the potential for its usage in different contexts and the benefits for all parties.

\section{REFERENCES}

[1] Abrenica, Y., "Electronic portfolios", College of Education, San Diego State University, USA, 1996, retrieved from http://edweb.sdsu.edu/courses/edtec596r/students/abrenica/abreni ca.html (August 2009)

[2] Attwell, G., "The Personal Learning Environments - the future of eLearning?", eLearning Papers, 2(1), Barcelona, Spain, 2007, retrieved from http://www.elearningeuropa.info/files/media/ media11561.pdf (September 2009)

[3] Balaban I., Divjak, B. and Kopić, M., "Emerging issues in using ePortfolio", Proceedings of the iLearning Forum 2010 London, Serge Ravet (Ed.),London, United Kingdom, 2010, pp. 212-218

[4] Balaban I. and Kišasondi, T., "A Lightweight ePortfolio Artefact Integrity Method", Proceedings of the ICL 2009 conference: The Challenges of Life Long Learning, Villach, Austria, 2009, pp. 681-686

[5] Balaban, I., "First steps in using ePortfolio in a university course", in E-learning new tendencies and innovation didactic activities, Ana Landeta Etxeberria (Ed.), CEF, Spain, 2010, pp. 155-164

[6] Barker, K.C., " ePortfolio Quality Standards: An International Development Project", discussion paper, FuturEd, Vancouver, $\begin{array}{lll}\text { Canada, } & \text { September 2003, retrieved from }\end{array}$ http://www.futured.com/pdf/ePortfolio\%20Quality\%20Discussio n\%20Paper.pdf (January, 2010)

[7] Barret, H. C., "Strategic questions: What to consider when planning for electronic portfolios", Learning\&Leading with Technology, 26(2), 1998, pp. 6-13, retrieved from http://electronicportfolios.org/portfolios/LLTOct98.html (October 2009)

[8] Batson, T., "The electronic portfolio boom: what's it all about?", Campus Technology, New York, USA, 2002, retrieved from http://www.campustechnology.com/Articles/2002/11/TheElectronic-Portfolio-Boom-Whats-it-All-About.aspx (August 2009)

[9] Bisovsky G. and Schaffert S., "Learning and Teaching with EPortfolios: Experiences in and Challenges for Adult Education", International Journal of Emerging Technologies in Learning, 2009, 4(1), pp. 13-15 
[10] Blackburn, J.L. and Hakel, M.D., "Enhancing Self-Regulation and Goal Orientation with ePortfolios", in Handbook of Research on ePortfolios, Jafari A.\&Kaufman C. (Ed.), IGI Global, London, UK, 2006, pp. 83-89. http://dx.doi.org/10.4018/978-159140-890-1.ch009

[11] Brant, J., "Factors affecting use / non-use of ePortfolios by learners", Report from EPISTLE Project, University of Wolverhampton, 2006, retrieved from http://www.jiscinfonet.ac.uk/case-studies/e-portfolios/wolverham pton/epistleguide5.pdf (January 2009)

[12] Challis D., "Towards the mature ePortfolio: Some implications for higher education", Canadian Journal of Learning and Technology, 31(3), 2005

[13] Doig B., Ilisley, B., McLuckie, J. and Parsons, R., "Using ePortfolios to Enhance Reflective Learning and Development", Handbook of Research on ePortfolios, Jafari A.\&Kaufman(Ed.) C., IGI Global, London, 2006, pp. $158-167$

[14] Electronic Portfolio Consortium, "Electronic Portfolio White Paper", Version 1.0, 2003, retrieved from http://eportconsortium.org (May 2009)

[15] Emmett D., Harper, W. and Hauville, K., "Creating a Strategy for the Implementation of the QUT ePortfolio", in Handbook of Research on ePortfolios, Jafari A.\&Kaufman C. (Ed.), IGI Global, London, UK, 2006, pp. $410-419$

[16] Fernández O. L., "Digital learner portfolio as a tool for innovating assessment in the European Higher Education Area", Interactive Educational Multimedia, No. 16, April 2008, pp. 54 65

[17] Flanigan E. and Amirian, S., "ePortfolios: Pathway from Classroom to Career", in Handbook of Research on ePortfolios, Jafari A.\&Kaufman C. (Ed.), IGI Global, London, 2006, pp. 102 -111. http://dx.doi.org/10.4018/978-1-59140-890-1.ch011

[18] Gathercoal P., Love, D., Bryde, B. and McKean, G., "On Implementing Web-Based Electronic Portfolios", Educause Quarterly, No. 2, 2002, pp. $29-37$

[19] Gibson D. and Barrett, H., "Directions in electronic portfolio development", Contemporary Issues in Technology and Teacher Education, 2(4), 2003, pp. 559-576, retrieved from http://www.citejournal.org/vol2/iss4/general/CITEGibsonGeneral 2.pdf (February 2009)

[20] Gibson D., "ePortfolio Decisions and Dilemmas", in Handbook of Research on ePortfolios, Jafari A.\&Kaufman C. (Ed.), IGI Global, London, UK, 2006, pp. 135 - 145

[21] Grant S., Marshall, A., Strivens, J. and Clark, R., "Development Issues for PDP with ePortfolios: Web Services and Skills", in Handbook of Research on ePortfolios, Jafari A.\&Kaufman C. (Ed.), IGI Global, London, UK, 2006, pp. $146-157$. http://dx.doi.org/10.4018/978-1-59140-890-1.ch015

[22] Grant S. and Richardson, H., "PDP Generic activity types version 2.5", The Centre for Recording Achievement, 2006, retrieved from http://zope.cetis.ac.uk/members/PDPcontent/view ActivityTypes (September 2009)

[23] Gray L., "Effective Practice with e-Portfolios", Higher Education Funding Council for England, JISC, Bristol, 2008, retrieved from http://www.jisc.ac.uk/media/documents/publications/effectivepra cticeeportfolios.pdf (January, 2010)

[24] Hargreaves D., "Learning for life: The foundations of lifelong learning", The Policy Press, Bristol, 2004

[25] Hartnell-Young E., "Impact study of e-portfolios on learning", Becta, 2007, retrieved from http://partners.becta.org.uk/uploaddir/downloads/page documents/research/impact_study eportfoli os.doc (February, 2010)

[26] Hickerson C. and Preston, M., "Transition to ePortfolios: A Case Study of Student Attitudes", in Handbook of Research on ePortfolios, Jafari A.\&Kaufman C. (Ed.), IGI Global, London, UK, 2006, pp. $460-473$

[27] Himpsl K. and Baumgartner P., "Evaluation of e-Portfolio Software", International Journal of Emerging Technologies in Learning, 2009, 4(1), pp. 16-22

[28] Jafari A., "The sticky e-portfolio system: Tackling challenges and identifying attributes", Educause Review, 39(4), 2004, pp. 38-49
[29] Laudon K.C. and Laudon, J.P., "Essentials of Management Information Systems: Managing the Digital Firm", 5th Edition, Prentice Hall, New Jersey, 2002

[30] Lorenzo G. and Ittelson, J., "Demonstrating and assessing student learning with e-portfolios", Educause Learning Initiative Paper, 3, 2005, retrieved from http://net.educause.edu/ir/library/pdf/EL I3003.pdf (December 2009)

[31] Love D., McKean, G. and Gathercoal, P., "Portfolios to Webfolios and Beyond: Levels of Maturation", Educause Quarterly, No. 2, 2004, pp. $24-37$

[32] Martins I., Correia, T. and Soeiro,A., "Digital Portfolios in University of Porto: defining goals", University of Porto, 2008, retrieved from http://repositorio.up.pt/aberto/bitstream/10216/ $13802 / 2 /$ Digital $\% 20$ Portfolios $\% 20 \mathrm{in} \% 20$ University $\% 20 \mathrm{of} \% 20 \mathrm{Po}$ rto\%20defining\%20goals.pdf (November 2009)

[33] O’Brien K., "ePortfolios as Learing Construction Zones: Provost's Perspective", in Handbook of Research on ePortfolios, Jafari A.\&Kaufman C. (Ed.), IGI Global, London, UK, 2006, pp. 74 - 82. http://dx.doi.org/10.4018/978-1-59140-890-1.ch008

[34] O'Brien K., "ePortfolios as Learing Construction Zones: Provost's Perspective", in Handbook of Research on ePortfolios, Jafari A.\&Kaufman C. (Ed.), IGI Global, London, UK, 2006, pp. 74 - 82. http://dx.doi.org/10.4018/978-1-59140-890-1.ch008

[35] Paulson F. L., Paulson, P. R. and Meyer, C., "What makes a portfolio a portfolio?", Educational Leadership, 48(5), 1991, pp. 60-63

[36] Riedinger B., "Mining for Meaning: Teaching Students How to Reflect", in Handbook of Research on ePortfolios, Jafari A.\&Kaufman C. (Ed.), IGI Global, London, UK, 2006, pp. 90 101. http://dx.doi.org/10.4018/978-1-59140-890-1.ch010

[37] Ring G. and Foti, S., "Using ePortfolios to Facilitate Professional Development Among Pre-Service Teachers", in Handbook of Research on ePortfolios, Jafari A.\&Kaufman C. (Ed.), IGI Global, London, UK, 2006, pp. 340 - 355

[38] Schugurensky, D., "The forms of informal learning: Towards a conceptualization of the field", The Research Network on New Approaches to Lifelong Learning, Ontario Institute for Studies in Education of the University of Toronto, October 2000, Canada, retrieved from http://www.oise.utoronto.ca/depts/sese/csew/ nall/res/19formsofinformal.htm (November 2009)

[39] Stefani L., Mason, R. and Pegler, C., "The educational potential of e-Portfolios", Routledge T\&F Group, Great Britain, 2007

[40] Stevenson H. J., "Using ePortfolios to Foster Peer Assessment, Critical Thinking, and Collaboration", in Handbook of Research on ePortfolios, Jafari A.\&Kaufman C. (Ed.), IGI Global, London, UK, 2006, pp. $112-123$

[41] Tosh D. and Werdmuller, B., "E-portfolios and Weblogs: One vision for e-portfolio development", 2004, retrieved from: http://eduspaces.net/bwerdmuller/files/61/178/ePortfolio_Weblog pdf (March, 2010)

[42] Zhang X, Olfman L, Ractham P. and Firpo D., "The Implementation and Evaluation of KEEP SLS: An ePortfolio System Supporting Social Constructive Learning", Proceedings of the Special interest Group on Management Information System's 47th Annual Conference on Computer Personnel, Limerick, Ireland, 2009, pp. 13-18.

\section{AUTHORS}

I. Balaban is with the University of Zagreb, Faculty of Organization and Informatics, 42000 Varaždin, Croatia (email: igor.balaban@foi.hr).

B. Divjak is with the University of Zagreb, Faculty of Organization and Informatics, 42000 Varaždin, Croatia (email: blazenka.divjak@foi.hr).

E. Mu is with the Carlow University, Pittsburgh, PA 15213 USA (e-mail: emu@carlow.edu).

Received March $11^{\text {th }}, 2011$. Published as resubmitted by the authors August $2^{\text {nd }}, 2011$. 